CATALLAXY

Volume 3 Issue 1 June 2018

e-ISSN 2544-090X

C www.catallaxy.pl

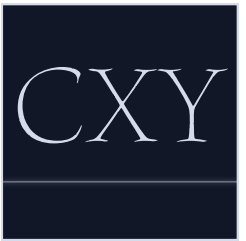

Oryginalny artykut naukowy

otrzymano: 07.05.2018 / zaakceptowano: 25.06.2018 / opublikowano online: 30.06 .2018

Jakubów, E. (2018). Konkurencyjność instytucjonalna państw OECD. Catallaxy, 3(1): 5-15.

doi:10.24136/cxy.2018.003.

\title{
Konkurencyjność instytucjonalna państw OECD
}

\author{
ELŻBIETA JAKUBÓW \\ Szkoła Głowna Handlowa w Warszawie, al. Niepodległości 162, 02-554 Warszawa, Polska \\ \ej60504@student.sgh.waw.pl \\ (iD) orcid.org/0000-0002-8103-6405
}

\begin{abstract}
Abstrakt
Motywacja: W artykule podjęto próbę sprawdzenia, czy oprócz zmiennych o charakterze czysto ekonomicznym, znaczenie dla wzrostu gospodarczego i nierówności dochodowych w państwach OECD mają również czynniki instytucjonalne.

Cel: Celem artykułu jest empiryczna analiza wpływu instytucji powiązanych z sektorem publicznym: korupcji, ochrony praw własności, restrykcyjności polityki ekologicznej i niezależności sądownictwa na sukces socjoekonomiczny społeczeństw państw OECD.

Materiały i metody: W analizie empirycznej wykorzystano dane panelowe dla jednorodnej grupy dziewiętnastu państw OECD o wysokim dochodzie w latach 2005-2012. Sukces socjoekonomiczny zoperacjonalizowano przy pomocy dwóch zmiennych: wzrostu gospodarczego oraz nierówności dochodowych. Ekonometryczny model wzrostu gospodarczego, oparty na modelu Solowa rozszerzonym o instytucje i kapitał ludzki, oszacowano ważoną metodą najmniejszych kwadratów, zaś w przypadku nierówności dochodowych zastosowano model efektów stałych uwzględniający, podobnie jak model wzrostu, zarówno zmienne instytucjonalne, jak i kontrolne.

Wyniki: Na podstawie wyników estymacji modeli ekonometrycznych wykazano istotny statystycznie wpływ restrykcyjności polityki ekologicznej na wzrost gospodarczy oraz ochrony praw własności na nierówności dochodowe. W obu modelach nieistotna statystycznie okazała się korupcja, zaś w modelu wzrostu - niezależność sądownictwa i ochrona praw własności.
\end{abstract}

Stowa kluczowe: konkurencyjnośc instytucjonalna; nowa ekonomia instytucjonalna; sektor publiczny; wzrost gospodarczy; indeks Giniego JEL: B52; E02; $017 ; 043$

\section{Wprowadzenie}

Konkurencyjność instytucjonalna nie jest pojęciem jednoznacznym. Koncepcja instytucji pojawiła się $\mathrm{w}$ naukach społecznych w pierwszej połowie XIX wieku. Początki instytucjonalizmu w ekonomii datuje się na lata 20. XX wieku. W okresie powojennym, stara ekonomia instytucjonalna uległa zmarginali- zowaniu, głównie przez brak podstaw teoretycznych (Rutherford, 2001, s. 183).

Niniejszy artykuł wpisuje się $z$ kolei w nurt nowej ekonomii instytucjonalnej. Koncepcja ta rozwinęła się w latach 70. XX wieku. Jej celem jest włączenie instytucji do teorii ekonomii. Inaczej jednak niż w przypadku starej ekonomii instytucjonalnej, jej przedstawiciele nie dążą do odrzucenia i zastąpienia 
teorii neoklasycznej. Co więcej, traktują ją jako podstawę, która wymaga jednak uzupełnienia i pewnych modyfikacji.

W ten sposób zachowane zostaje założenie o rzadkości dóbr, a w konsekwencji o konkurencji między podmiotami gospodarującymi. Nowa ekonomia instytucjonalna rezygnuje natomiast $z$ założenia o racjonalności instrumentalnej. Ponieważ jej konsekwencją jest brak asymetrii informacyjnej, nieefektywności rynków, czy ograniczonych zdolności umysłowych jednostek, istnienie instytucji przy takim założeniu nie miałoby uzasadnienia (North, 1993, s. 1).

Jeden $z$ najbardziej znaczących przedstawicieli nowej ekonomii instytucjonalnej, D.C. North (1990, s. 3), zdefiniowat instytucje jako „reguły gry w społeczeństwie, czy też bardziej formalnie, ograniczenia stworzone przez ludzi, które kształtują interakcje między nimi. W konsekwencji organizują one bodźce w procesie wymiany, które mogą mieć charakter polityczny, społeczny czy ekonomiczny"1. Składają się na nie reguły formalne, nieformalne oraz sposoby ich egzekwowania.

D.C. North (1993, s. 6), podkreśla różnicę między instytucjami a organizacjami definiowanymi jako gracze: grupy osób połączonych wspólnym zamiarem osiągnięcia pewnych celów.

Rola instytucji polega na zmniejszaniu niepewności i asymetrii informacyjnej, jak również kosztów produkcji i kosztów transakcyjnych. Ponadto, ułatwiają one specjalizację i podział pracy. Mogą też jednak ujemnie wpływać na wyniki gospodarcze, jeśli wprowadzane są przez jednostki, które kierują się wyłącznie własnym interesem (North, 1991, s. 98; 2003, ss. 1, 5-6).

Istnieje wiele definicji pojęcia „konkurencyjność." Dotyczy ono również różnych poziomów, np. przedsiębiorstw, sektorów, regionów czy organizacji ponadnarodowych. W niniejszym artykule skupiono się wyłącznie na koncepcji konkurencyjności społeczeństwa.

Według M.A. Weresy (2014, s. IX), konkurencyjność oznacza „utrzymywanie

${ }^{1}$ Wszelkie teksty tłumaczone z języka angielskiego na polski, Elíbieta Jakubów. długoterminowej przewagi konkurencyjnej w handlu międzynarodowym, analizowanej na podstawie wskaźnika konkurencyjności eksportu". Za najważniejsze czynniki konkurencyjności uznawane są $\mathrm{w}$ tym przypadku innowacje i kapitał ludzki.

Według J. Fagerberga: konkurencyjność odzwierciedla „zdolność państwa do osiągania zasadniczych celów polityki gospodarczej, zwłaszcza wzrostu dochodu i zatrudnienia bez popadania $\mathrm{w}$ trudności $\mathrm{w}$ odniesieniu do bilansu płatniczego", względnie „zdolność państwa do zapewnienia wysokiego standardu życia swoim obywatelom w porównaniu $z$ obywatelami innych państw teraz i w przyszłości". Zdaniem J. Fagerberga najważniejszymi czynnikami konkurencyjności są: zasoby, struktura przemysłowa, technologiczna i instytucjonalna oraz handel zagraniczny (Aiginger, 2006, s. 166; Hinrikus i in., 2000, ss. 17-18).

Niniejszy artykuł oparto na specyficznej koncepcji konkurencyjności, w której, inaczej niż w większości przypadków, zmienne pozaekonomiczne uznawane są za kluczowe czynniki konkurencyjności.

O.K. Pedersen (2010), definiuje konkurencyjność instytucjonalną jako „zdolność państwa do osiągnięcia sukcesu socjoekonomicznego $\mathrm{w}$ stosunku do porównywalnych państw, dzięki instytucjom politycznym i ekonomicznym".

Istnieje wiele instytucji, które mogą się potencjalnie przyczynić do osiągnięcia sukcesu socjoekonomicznego przez dane państwo. Również sam sukces może być rozumiany na wiele sposobów. Niniejszy artykuł oparto na analizie wybranych instytucji, związanych ze sferą publiczną, zaś miarami sukcesu są: wzrost gospodarczy, przy pomocy którego zoperacjonalizowano sukces ekonomiczny oraz podział dochodu będący uproszczoną miarą sukcesu społecznego.

Do analizowanych instytucji należą: korupcja, ochrona praw własności, restrykcyjność polityki ekologicznej oraz niezależność sądownictwa.

Przy analizie wpływu instytucji na wzrost gospodarczy i podział dochodu należy mieć 
na uwadze, że nie istnieje uniwersalna kombinacja instytucji, która pozwoliłaby stworzyć dogodne warunki do rozwoju społecznego i ekonomicznego $w$ dowolnym państwie. Co więcej, te same instytucje mogą mieć $\mathrm{w}$ różnych okolicznościach korzystny lub negatywny wpływ na wzrost i podział dochodu.

Ocenę konsekwencji istnienia poszczególnych instytucji utrudnia również ich wpływ na siebie nawzajem. Pojedyncze instytucje funkcjonują w szerszym systemie instytucjonalnym i stanowią dla siebie wzajemne ograniczenie (Carus i Ogilvie, 2014, s. 428). Mimo tych zastrzeżeń, w literaturze znaleźć można liczne przykłady włączania zmiennych instytucjonalnych do modeli ekonomicznych.

Celem artykułu jest empiryczna analiza wpływu instytucji powiązanych $z$ sektorem publicznym: korupcji, ochrony praw własności, restrykcyjności polityki ekologicznej i niezależności sądownictwa na sukces socjoekonomiczny społeczeństw państw OECD.

W sekcji 2. przytoczono wyniki dotychczasowych badań dotyczących wpływu wybranych instytucji na wzrost gospodarczy i nierówności dochodowe. Zastosowane materiały i metody zaprezentowano $\mathrm{w}$ sekcji 3 . Wyniki analizy oraz ich podsumowanie zaprezentowano odpowiednio w sekcji 4 . i sekcji 5 .

\section{Przegląd literatury}

\subsection{Wpływ korupcji na wzrost gospodarczy i nierówności dochodowe}

Wpływ korupcji zarówno na wzrost, jak i na podział dochodu nie jest jednoznaczny, choć większość ekonomistów wskazuje na niekorzystne konsekwencje istnienia tej instytucji na obie zmienne.

H. Davoodi i V. Tanzi (1997, ss. 3-9, 20), wykazują szkodliwy wpływ korupcji na proces decyzyjny, związany $z$ inwestycjami publicznymi. W przypadku, gdy przedsiębiorstwa płacą urzędnikom za preferencyjne traktowanie $w$ przetargach, istnieje ryzyko przeznaczenia zbyt wielu środków na duże projekty takie, jak drogi czy elektrownie. Tracą na tym projekty mniej atrakcyjne politycznie, jak np. utrzymanie i konserwacja infrastruktury. W konsekwencji pojawiają się problemy $z$ utrzymaniem istniejącego kapitału fizycznego. Ponadto, zwiększenie nakładów na inwestycje publiczne wiąże się ze spadkiem ich produktywności. Traktowanie zysku wykonawcy jako głównego kryterium przy wyborze projektów inwestycyjnych, prowadzi do lekceważenia ekonomicznej zasadności projektów w szerszym znaczeniu. Wspomniane czynniki skutkują spowolnieniem wzrostu gospodarczego.

P. Mauro (1995, s. 683), wskazuje z kolei na negatywny wpływ korupcji na prywatne inwestycje. Niektórzy autorzy dowodzą jej szkodliwemu oddziaływaniu na poziom bezpośrednich inwestycji zagranicznych (BIZ) w państwie, do którego napływają. A. Cuervo-Cazurra zwraca dodatkowo uwage na to, że w strukturze BIZ zaczynają przeważać inwestycje z państw o podobnym poziomie korupcji co państwo, które je przyjmuje. Korupcja może też powodować wzrost kosztów inwestycyjnych (Chene, 2014, ss. 3-4).

Według G. Attila (2008, s. 3, 23), korupcja powoduje zmniejszenie stopnia przestrzegania przepisów podatkowych przez podatników, co prowadzi do ograniczania wpływów budżetowych. To z kolei może się przyczynić do nadmiernego opodatkowania, które szkodzi wzrostowi gospodarczemu.

A. Dreher i T. Herzfeld zwracają z kolei uwagę na inną przyczynę zmniejszenia wpływów budżetowych: korupcja pogarsza jakość biurokracji, a co za tym idzie, zaufanie do administracji państwowej. W konsekwencji zwiększa się udział szarej strefy w gospodarce (Nawaz, 2010, s. 3).

W literaturze pojawiają się jednak również wnioski o korzystnym oddziaływaniu korupcji na wzrost. P. Meon i K. Sekkat (2005, ss. 71-73), argumentują, że korupcja pomaga niekiedy pominąć, trwający zbyt długo, biurokratyczny proces decyzyjny. Ponadto, perspektywa otrzymywania dodatkowego, nieformalnego wynagrodzenia może sprawić, że o stanowiska urzędnicze będą się ubiegały osoby bardziej wykwalifikowane, 
którym mogą nie wystarczać oficjalne pensje. $Z$ tego samego powodu może też potencjalnie wzrosnąć produktywność zatrudnionych już urzędników państwowych.

$\mathrm{Na}$ wspomniany już przypadek publicznych przetargów można spojrzeć $z$ innej strony. Jeśli wybierani są wykonawcy, których było stać na wyasygnowanie największej sumy na przekupienie urzędników mających wpływ na rozstrzygnięcie przetargu, niewykluczone, że również najefektywniej prowadzą swoją działalność.

Oprócz tego, korupcja może prowadzić do poprawy polityki publicznej. Omijanie pewnych regulacji prawnych może być wskazówką do wdrożenia korzystniejszych rozwiązań.

Korupcja może pogłębiać nierówności dochodowe, jeśli uchylanie się od płacenia podatków i zła jakość administracji podatkowej prowadzą do zmniejszenia podstawy opodatkowania i progresywności systemu podatkowego.

Innym problemem jest spadek skuteczności programów skierowanych do uboższej części społeczeństwa, kiedy przeznaczone dla niej środki przejmowane są przez lepiej sytuowanych członków społeczeństwa.

Korupcja prowadzić może także do zmniejszenia udziału inwestycji w projekty pracochłonne będące źródłem dochodu dla uboższych jednostek na rzecz projektów kapitałochłonnych (Alonso-Terme i in., 1998, ss. 4-7).

S. Akcay (2006, ss. 33-34, 45), wskazuje dodatkowo na aspekt korupcji, który prowadzi zarówno do pogłębienia nierówności dochodowych, jak i do ograniczenia wzrostu gospodarczego. Przyczynia się ona do ograniczenia wydatków na służbę zdrowia i system edukacji, ponieważ są to obszary, w których istnieje mniejsze pole do działań o charakterze korupcyjnym.

\subsection{Wpływ ochrony praw własności na wzrost gospodarczy i nierówności dochodowe}

W kontekście wpływu ochrony praw własności na wzrost, A.W. Carus i S. Ogilvie (2014, s. 444), argumentują, że jej obecność stymuluje wzrost gospodarczy, ponieważ aktywa trafiają wówczas do jednostek, które przypisują im najwyższą wartość, a w konsekwencji, $z$ dużym prawdopodobieństwem znajdują swoje najbardziej produktywne zastosowanie.

A. Durnev i in. (2009, ss. 1533-1534), dowodzą, że niedostateczna ochrona praw własności zmniejsza korzyści dla wzrostu gospodarczego płynące $z$ transparentności $w$ postaci łatwiejszego zawierania umów czy niższych kosztów zdobycia informacji. Duży stopień transparentności, w połączeniu $z$ niewystarczającą ochroną praw własności, może skutkować zwiększonym ryzykiem wywłaszczenia przedsiębiorców przez państwo.

Dodatkowe koszty mogą być również konsekwencją konieczności sfinansowania ochrony swojej własności w warunkach braku praw, które ją chronią (Besley i Ghatak, 2010, s. 4528).

Warto osobno rozważyć wpływ ochrony praw własności intelektualnej na wzrost gospodarczy. Ten bowiem nie jest jednoznaczny. Zwiększona ochrona tego rodzaju praw zachęca do inwestowania $z$ powodu wysokich zysków $z$ działalności innowacyjnej. $Z$ drugiej strony, rosną przez to koszty inwestycji dla innych przedsiębiorców, ponieważ muszą płacić za korzystanie $z$ opatentowanych produktów (Kim i in., 2012, s. 6).

A. Horowitz i C. Lai (1996, s. 796), wskazują na inny aspekt tego problemu. Im dłuższy czas trwania patentu, tym wyższe są zyski $z$ działalności innowacyjnej. $z$ drugiej strony, zmniejsza się wtedy częstotliwość innowacji, ponieważ inni przedsiębiorcy mogą korzystać z nowych rozwiązań dopiero po pewnym czasie.

Według R. Horii i T. Iwaisako (2006, ss. 48-49, 79), zwiększona ochrona praw własności intelektualnej wywiera raczej negatywny wpływ na wzrost. Powoduje ona spadek liczby konkurencyjnych sektorów na rzecz monopolistycznych, które stwarzają mniej dogodne warunki do rozwoju innowacji.

Większość ekonomistów wskazuje na potencjalny wzrost nierówności dochodowych na skutek zwiększonej ochrony praw własności intelektualnej. Dłuższy czas trwania 
patentów zwiększa dochody zatrudnionych w sektorze badań i rozwoju w stosunku do pozostałych pracowników. Zjawisko to, można szerzej określić jako zwiększanie się nierówności dochodowych między wykwalifikowaną i niewykwalifikowaną siłą roboczą (Kiedaisch, 2016, s. 2, 7, 31).

\subsection{Wpływ restrykcyjnej polityki ekologicznej na wzrost gospodarczy i nierówności dochodowe}

Restrykcyjna polityka ekologiczna może mieć szkodliwy wpływ na wzrost gospodarczy, ponieważ przysparza przedsiębiorstwom dodatkowych kosztów, ponoszonych na inwestycje $w$ technologie zmniejszające emisję zanieczyszczeń, co niekorzystnie odbija się na produktywności przedsiębiorstw. $Z$ drugiej strony, zgodnie $z$ hipotezą Portera, wspomniane inwestycje mogą zwiększyć innowacyjność przedsiębiorstwa, co z kolei podnosi produktywność jego procesów produkcyjnych.

Istnieją też niekorzystne dla wzrostu aspekty restrykcyjnych przepisów dotyczących ochrony środowiska. Przedsiębiorcy mogą przykładowo przenieść działalność gospodarczą za granicę, albo wręcz całkowicie opuścić rynek.

Innym potencjalnym problemem jest zwiększanie barier dostępu do rynku i w konsekwencji ograniczenie konkurencji (Albrizio i in., 2016, s. 6).

Niekorzystne mogą być także niewystarczające regulacje $\mathrm{w}$ dziedzinie ochrony środowiska. Jeśli przedsiębiorstwa ponoszą mniejsze koszty niż wynikałoby to ze stopnia, w jakim obciążają one środowisko, część kosztów musi ponieść społeczeństwo. Nieprawidłowe przyporządkowanie kosztów do podmiotów gospodarujących prowadzi do nieefektywności gospodarki (Congress of the United States, 1985, ss. 3-7).

$Z$ badań empirycznych wynika, że zaostrzenie polityki ekologicznej wiąże się ze wzrostem produktywności na poziomie krajowym i u najproduktywniejszych przedsiębiorstw. Prawdopodobnie dzieje się tak, ponieważ przedsiębiorstwa takie dysponowały nowoczesnymi technologiami jeszcze przed zaostrzeniem przepisów. Mogą tė̇ przeznaczyć większe środki na badania i rozwój niż podmioty mniej produktywne (Albrizio i in., 2016, s. 31).

Restrykcyjna polityka ekologiczna może zwiększyć wydajność gospodarki, ponieważ powoduje zmniejszenie wydatków na ochronę zdrowia, a w konsekwencji zwiększenie dochodu rozporządzalnego i konsumpcji (Congress of the United States, 1985, ss. 3-7).

Wpływ restrykcyjności polityki ekologicznej na nierówności dochodowe nie znalazł dotychczas potwierdzenia w literaturze.

\subsection{Wpływ niezależności sądownictwa na wzrost gospodarczy i nierówności dochodowe}

Niezależność sądownictwa korzystnie wpływa na wzrost gospodarczy, ponieważ wiąże się $z$ lepszą ochroną praw własności. Dzięki temu zmniejsza się niepewność, a rośnie skłonność do inwestowania (Feld i in., 2015, ss. 197198). Odwrotny skutek można potencjalnie zaobserwować, jeśli brak ograniczeń i nadzoru prowadzi do wydawania błędnych decyzji przez sądy. Wówczas niepewność wśród podmiotów gospodarujących rośnie (Hayo i Voigt, 2008, ss. 2-3).

D. Klerman (2006, s. 429), zwraca uwagę na istnienie mechanizmów, które mogą zastąpić niezależność sądów, przez co nie zawsze jest ona niezbędna dla ochrony praw własności. W małych społecznościach, obawa przed utratą dobrej opinii, albo przed odwetem, powstrzymuje ich członków przed naruszaniem prawa. Ponadto, upolitycznione sądy mogą wydawać sprawiedliwe wyroki chroniące prawa własności, jeśli żadna ze stron nie ma politycznego wsparcia. Skuteczność tego rodzaju mechanizmów jest jednak ograniczona.

W literaturze przedmiotu trudno znaleźć prace, które wskazywałyby na istotny wpływ niezależności sądownictwa na nierówności dochodowe.

\section{Materiały i metody}

W analizie wykorzystano dane roczne dotyczące lat 2005-2012. Dane odnośnie wzrostu 
gospodarczego, mierzonego stopą wzrostu realnego PKB na pracownika, pochodzą z bazy danych Banku Światowego (World Bank, 2018).

Za miernik nierówności dochodowej przyjęto indeks Giniego. Źródłem danych był Eurostat (2018) i OECD (2018).

Wskaźnik restrykcyjności polityki ekologicznej przyjmuje poziom od zera do sześciu, gdzie najwyższy poziom odpowiada najbardziej restrykcyjnym przepisom. Definiowany jest on jako „wyższe, jawne lub ukryte koszty zanieczyszczania lub zachowania szkodliwego dla środowiska" i pochodzi $z$ bazy danych OECD (2018).

Wskaźnik ochrony własności prywatnej skonstruowano $\mathrm{w}$ oparciu o wyniki ankiety przeprowadzonej wśród kadry zarządzającej, której zadawano pytanie: „w jakim stopniu chronione są prawa własności, $w$ tym prawa do aktywów finansowych w państwa kraju?" W przypadku braku ochrony praw własności, wskaźnik był równy jedności, jeśli prawa własności były bardzo dobrze chronione przyjmował maksymalny poziom wynoszący siedem.

Wskaźnik niezależności sądownictwa skonstruowano w oparciu o pytanie: „jak bardzo niezależny od wpływu rządu, osób fizycznych czy przedsiębiorstw jest system sądownictwa w państwa kraju?" skierowane do tej samej grupy odbiorców. Poziom tego wskaźnika mieścił się w przedziale od zera do siedmiu, gdzie najwyższy poziom oznaczał największą niezależność. Oba indeksy pocho$\mathrm{d} z a ̨$ z Globalnego raportu konkurencyjności, tworzonego przez Światowe Forum Ekonomiczne (World Economic Forum, 2016).

Dane dotyczące korupcji - ostatniej spośród zmiennych instytucjonalnych - zaczerpnięto $z$ raportu International country risk guide przygotowywanego przez Political Risk Services (2014). Ponieważ zmienna ta jest częścią indeksu zbiorczego, który przyjmuje wyższy poziom dla lepszych wyników, w przedziale od zera do jedności, im wyższy poziom wskaźnika, tym niższy poziom korupcji.

Początkowy poziom realnego PKB na pracownika ( $z$ roku 2005) uwzględniono w modelu, ponieważ można się spodziewać, że państwa zaczynające od niższego poziomu PKB, osiągną wyższą stopę wzrostu niż państwa zamożniejsze. Źródłem danych była baza Banku Światowego (World Bank, 2018).

Wzrost siły roboczej powoduje spadek PKB na pracownika przy braku nowych inwestycji i amortyzacji, ponieważ spada wówczas poziom kapitału na pracownika. Szereg czasowy dotyczący stopy wzrostu siły roboczej zaczerpnięto $z$ Ifo Institute (2016).

Udział inwestycji w PKB zmierzono za pomocą nakładów brutto na środki trwałe.

Wskaźnik kapitału ludzkiego oparto na liczbie lat spędzonych na edukacji oraz na zwrocie z edukacji.

Otwartość handlową wyrażono przy pomocy udziału sumy eksportu i importu w PKB.

Całkowita produktywność czynników produkcji (total factor productivity, TFP) pochodzi $z$ Groningen Growth and Development Centre (2018), podobnie, jak udział inwestycji w PKB, wskaźnik kapitału ludzkiego i otwartość handlowa.

Analiza empiryczna obejmuje dwa modele oparte na danych panelowych. Model wzrostu na pracownika oszacowano ważoną metodą najmniejszych kwadratów, ponieważ test Breuscha-Pagana wykazał nieistotność efektów indywidualnych. Ten sam test wskazał na istotność efektów indywidualnych w przypadku modelu tłumaczącego zmienność indeksu Giniego. Na podstawie wyników testu Hausmana oszacowano model efektów stałych. Badany okres obejmuje lata 20052012. Brakujące dane w każdym wypadku zastąpiono przez ostatnią, obserwowaną wartość danej zmiennej. Nie pozostaje to wprawdzie bez konsekwencji dla jakości modeli, lecz stosunek brakujących wartości do całego zbioru danych był niewielki. Dlatego też nie powinno to wpłynąć znacząco na jakość oszacowań.

Modele oszacowano dla dziewiętnastu państw OECD o wysokim dochodzie. Są to: Niemcy, Austria, Finlandia, Szwecja, Dania, Holandia, Belgia, Francja, Hiszpania, Włochy, Portugalia, Zjednoczone Królestwo, Norwegia, Kanada, Czechy, Irlandia, Polska, Słowacja i Słowenia. Celem było znalezienie 
jednorodnej grupy wysoko rozwiniętych, demokratycznych państw, o dojrzałych instytucjach, powiązanych $z$ sektorem publicznym. Ważnym kryterium była również dostępność danych.

Model (1), w którym zmienną zależną jest wzrost realnego $\mathrm{PKB}$ na pracownika, opart0 na modelu Solowa rozszerzonym o instytucje i kapitał ludzki. Model dany jest równaniem (1):

$$
\begin{aligned}
& \mathrm{PKB}_{i, t}=\alpha_{0}+\alpha_{1} \mathrm{KOR}_{i, t}+ \\
& +\alpha_{2} \mathrm{NS}_{i, t}+\alpha_{3} \mathrm{RPE}_{i, t}+\alpha_{4} \mathrm{OPW}_{i, t}+ \\
& +\alpha_{5} \mathrm{INW}_{i, t}+\alpha_{6} \mathrm{KL}_{i, t}+\alpha_{7} \mathrm{PPKB}_{i, t}+ \\
& +\alpha_{8} \ln \mathrm{WSR}_{i, t}+\varepsilon_{i, t} .
\end{aligned}
$$

W modelu objaśniającym zmienność indeksu Giniego (model (2)), podobnie jak w modelu wzrostu PKB na pracownika, zawarto zmienne instytucjonalne (dwie spośród czterech omawianych $\mathrm{w}$ niniejszym artykule, ponieważ $w$ przypadku pozostałych dwóch nie wykazano $w$ literaturze ich znaczącego wpływu na podział dochodu) oraz zmienne kontrolne. Model dany jest równaniem (2):

$$
\begin{aligned}
& \ln \mathrm{GINI}_{i, t}=\beta_{0}+\beta_{1} \ln \mathrm{KL}_{i, t}+ \\
& +\beta_{2} \ln \mathrm{TFP}_{i, t}+\beta_{3} \ln \mathrm{OH}_{i, t}+ \\
& +\beta_{4} \ln \mathrm{KOR}_{i, t}+\beta_{5} \ln O P W_{i, t}+ \\
& +\varepsilon_{i, t},
\end{aligned}
$$

gdzie:

$i=1,2, \ldots, 19$;

$t=1,2, \ldots, 8$.

$\mathrm{W}$ modelach zastosowano następujące oznaczenia:

$P K B_{i, t}$ - stopa wzrostu realnego PKB per capita $\mathrm{w}$ i-tym państwie $\mathrm{w}$ okresie $t$ (w\%);

$\mathrm{KOR}_{i, t}$ - wskaźnik korupcji w i-tym panstwie w okresie t;

$\mathrm{NS}_{i, t}$ - wskaźnik niezależności sądownictwa w $i$-tym państwie w okresie $t$;

$R P E_{i, t}$ - wskaźnik restrykcyjności polityki ekologicznej w i-tym państwie w okresie $t$;

$O P W_{i, t}$ - wskaźnik ochrony własności prywatnej $\mathrm{w} i$-tym państwie $\mathrm{w}$ okresie $t$;
INW $_{i, t}$ - udział inwestycji w PKB w i-tym państwie w okresie $t$ (w \%);

$\mathrm{KL}_{i, t}$ - wskaźnik kapitału ludzkiego w i-tym państwie w okresie $t$;

$P P K B_{i+t}$ - początkowy poziom realnego PKB na pracownika (z 2005 roku) w i-tym państwie w okresie $t$;

$\ln W S R_{i, t}$ - logarytm stopy wzrostu siły roboczej w $i$-tym państwie w okresie $t$;

ln $\mathrm{GINI}_{i, t,}$ - logarytm indeksu Giniego w i-tym państwie w okresie $t$;

$\ln \mathrm{KL}_{i, t}$ - logarytm wskaźnika kapitału ludzkiego $\mathrm{w} i$-tym państwie $\mathrm{w}$ okresie $t$

$\operatorname{lnTFP} P_{i, t,}$ - logarytm całkowitej produktywności czynników produkcji w i-tym państwie w okresie $t$;

$\ln \mathrm{OH}_{i, t}-$ logarytm poziomu otwartości handlowej w $i$-tym państwie w okresiet;

$\operatorname{lnKOR}_{i, t}$ - logarytm poziomu korupcji w $i$-tym państwie w okresie $t$;

lnOPW $W_{i, t}$ - logarytm poziomu otwartości handlowej $w i$-tym państwie $w$ okresie $t$;

$\alpha_{0}, \beta_{0}-$ wyrazy wolne;

$\alpha_{\text {; }} \beta_{\mathrm{k}}$ - parametry strukturalne;

$\varepsilon_{i, t}-$ składniki losowe.

\section{Wyniki badania}

W modelu, w którym zmienną objaśnianą był realny wzrost PKB na pracownika (model (1)), statystycznie istotny wpływ uzyskano w przypadku następujących zmiennych kontrolnych: początkowy poziom PKB na pracownika, udział inwestycji w PKB, wzrost siły roboczej i kapitał ludzki. Wszystkie zmienne, oprócz wzrostu siły roboczej, wykazały przewidziany w literaturze (Vijayaraghavan i Ward, 2001, ss. 10-13) kierunek oddziaływania (tabela 1.).

Spośród zmiennych instytucjonalnych tylko jedna $z$ nich (restrykcyjność polityki ekologicznej) okazała się istotna statystycznie (tabela 1.). Zaostrzenie przepisów dotyczących ochrony środowiska, zgodnie $z$ modelem (1), wpływała negatywnie na wzrost PKB na pracownika. W świetle dotychczasowych 
badań, jest to wynik mający ekonomiczne uzasadnienie.

W modelu tłumaczącym zmienność indeksu Giniego (model (2)), statystycznie istotne okazały się dwie $z$ trzech zmiennych kontrolnych: otwartość handlowa oraz całkowita produktywność czynników produkcji. Kierunek oddziaływania TFP był zgodny ze wykazanym $w$ wielu poprzednich badaniach (Sequeira i in., 2014, ss. 7-21) (tabela 2.).

Ze zmiennych instytucjonalnych, statystycznie istotna okazała się ochrona praw własności (tabela 2.). Kierunek oddziaływania tej zmiennej, inaczej niż w większości badań, był ujemny.

Przyczynami niejasnego i nie zawsze zgodnego $z$ wynikami dotychczasowych badań wpływu niektórych spośród analizowanych zmiennych na wzrost i nierówności dochodowe może być potencjalnie niewystarczająca, choć względnie duża, liczba obserwacji oraz wspomniane ograniczenia, związane $z$ analizą wpływu instytucji na wzrost i nierówności dochodowe.

\section{Zakończenie}

Zarówno oszacowane $\mathrm{w}$ niniejszym artykule modele, jak i dotychczasowe badania wskazują, że sukces socjoekonomiczny zależy nie tylko od zmiennych o charakterze czysto ekonomicznym. Duże znaczenie ma też otoczenie instytucjonalne $\mathrm{w}$ danym państwie.

Celem uzyskania pewniejszych wyników, wskazane byłoby zbadanie wpływu instytucji sektora publicznego w oparciu o bardziej kompletne dane i dłuższe szeregi czasowe.

\section{Bibliografia}

Aiginger, K. (2006). Competitiveness: from a dangerous obsession to a welfare creating ability with positive externalities. Journal of Industry, Competition and Trade, 6(2). doi:10.1007/ s10842-006-9475-6.

Akcay, S. (2006). Corruption and human development. Cato Journal, 26(1).
Albrizio, S., Koźluk, T., i Zipperer, V. (2014). Empirical evidence on the effects of environmental policy stringency on productivity growth. OECD Economics Department Working Papers, 1179 doi:10.1787/5jxrjnb36b40-en.

Alonso-Terme, R., Davoodi, H., Gupta, S. (1998). Does corruption affect income inequality and poverty? IMF Working Papers, 98(76). doi:10.5089/9781451849844.001.

Attila, G. (2008). Corruption, taxation and economic growth: theory and evidence. CERDI Working Paper, E2008.29. doi:10.2139/ ssrn.2260995.

Besley, T., i Ghatak, M. (2010). Property rights and economic development. W: D. Rodrik, i M. Rosenzweig (red.), Handbook of development economics. Amsterdam: Elsevier. doi:10.1016/ B978-0-444-52944-2.00006-9.

Carus, A.W., i Ogilvie, S. (2014). Institutions and economic growth in historical perspective. W: P. Aghion, i S.N. Durlauf (red.), Handbook of economic growth. Amsterdam: Elsevier. doi:10.1016/b978-0-444-53538-2.00008-3.

Chene, M. (2014). The impact of corruption on growth and inequality. Pobrane 01.05.2016 z http:// www.transparency.org.

Congress of the United States. (1985). Environmental Regulation and Economic Efficiency. Pobrane 07.05.2016 z https://www.cbo.gov.

Davoodi, H., i Tanzi, V. (1997). Corruption, public investment and growth. W: T. Ihori, i H. Shibata (red.), The welfare state, public investment, and growth. Tokyo: Springer. doi:10.1007/978-4-431-67939-4_4.

Durnev, A., Errunza, V., i Molchanov, A. (2009). Property rights protection, corporate transparency, and growth. Journal of International Business Studies, 40(9). doi:10.1057/jibs.2009.58.

Eurostat. (2018). Pobrane 13.05.2016 z http:// ec.europa.eu/eurostat.

Feld, L., Gutmann, J., i Voigt, S. (2015). Economic growth and judicial independence, a dozen years on: cross-country evidence using an updated set of indicators. European Journal of Political Economy, 38. doi:10.1016/j. ejpoleco.2015.01.004.

Groningen Growth and Development Centre. (2018). Penn World Table. Pobrane 12.04.2018 $z$ https://www.rug.nl. doi:10.15141/S5J01T.

Hayo, B., i Voigt, S. (2008). The relevance of judicial procedure for economic growth. CESifo Economic Studies, 60(3). doi:10.1093/cesifo/ifs044.

Hinrikus, M., Ivanov, A., i Reiljan, J. (2000). Key issues in defining and analysing the competitiveness of a country. Tartu: Tartu University Press. 
Horii, R., i Iwaisako, T. (2006). Economic growth with imperfect protection of intellectual property rights. Journal of Economics, 90(1). doi:10.1007/s00712-006-0222-6.

Horowitz, A., i Lai, C. (1996). Patent length and the rate of innovation. International Economic Review, 37(4). doi:10.2307/2527311.

Ifo Institute. (2016). Database for institutional comparisons in Europe. Pobrane 16.05.2016 z http:// www.cesifo-group.de.

Kiedaisch, C. (2016). Growth and welfare effects of intellectual property rights when consumers differ in income. University of Zurich Department of Economics Working Paper, 221. doi:10.2139/ ssrn. 2753615.

Kim, Y., Lee, K., i Park, W. (2012). Appropriate intellectual property protection and economic growth in countries at different levels of development. Research Policy, 41(2). doi:10.1016/j. respol.2011.09.003.

Klerman, D. (2006). Legal infrastructure, judicial independence, and economic development. USC Center in Law, Economics and Organization Research Paper, C06-1. doi:10.2139/ssrn.877490.

Mauro, P. (1995). Corruption and growth. Quarterly Journal of Economics, 110(3). doi:10.2307/2946696.

Meon, P., i Sekkat, K. (2005). Does corruption grease or sand the wheels of growth? Public Choice, 122(1-2). doi:10.1007/s11127-005-3988-0.

Nawaz, F. (2010). Exploring the relationships between corruption and tax revenue. Pobrane: 01.05.2016 z http://www.u4.no.

North, D.C. (1990). Institutions, institutional change and economic performance. Cambridge: Cambridge University Press. doi:10.1017/ CBO9780511808678.

North, D.C. (1991). Institutions. Journal of Economic Perspectives, 5(1). doi:10.1257/jep.5.1.97.

North, D.C. (1993). The new institutional economics and development. Pobrane 25.03.2016 z https:// econpapers.repec.org.

North, D.C. (2003). The role of institutions in economic development. ECE Discussion Papers Series, 2003.2.

OECD. (2018). Pobrane 16.05.2016 z http://stats. oecd.org.
Pedersen, O.K. (2010). Institutional competitiveness: how nations came to compete. W: G. Morgan, J.L. Campbell, C. Crouch, O.K. Pedersen, i R. Whitley (red.), The Oxford handbook of comparative institutional analysis. New York: Oxford University Press. doi:10.1093/ oxfordhb/9780199233762.003.0023.

Political Risk Services. (2014). International country risk guide. Pobrane 14.07.2018 z http://www. prsgroup.com.

Rutherford, M. (2001). Institutional economics: then and now. Journal of Economic Perspectives, 5(13). doi:10.1257/jep.15.3.173.

Sequeira, T.N., Santos, M., i Ferreira-Lopes, A. (2017). Income inequality, TFP, and human capital. Economic Record, 93(300). doi:10.1111/1475-4932.12316.

Vijayaraghavan, M., i Ward, W. (2001). Institutions and economic growth: empirical evidence for a cross-national analysis. Center for International Trade Working Paper, 001302.

Weresa, M.A. (2014). Innovation, human capital and trade competitiveness. How are they connected and why do they matter? Comparing countries in Europe, North America and Asia. Washington: Springer. doi:10.1007/978-3-319-02072-3.

World Bank. (2018). Pobrane 12.04.2018 z http:// databank.worldbank.org.

World Economic Forum. (2016). The global competitiveness report 2015-2016. Pobrane 16.05.2016 $z$ http://reports.weforum.org.

Informacje uzupełniające

Wkład autorski: autor zaakceptował ostateczną wersję artykułu.

Źródła finansowania: artykuł został w całości sfinansowany ze środków własnych autora.

Uwagi: wyniki badania byly zaprezentowane na VIII Ogólnopolskiej Konferencji Naukowej z cyklu Problemy gospodarki światowej (Toruń, 20.04.2018) 
Aneks

Tabela 1.

Wyniki estymacji modelu objaśniającego wzrost gospodarczy na pracownika (model (1))

\begin{tabular}{lcc}
\hline \multicolumn{1}{c}{ Zmienna objaśniająca } & Współczynnik & Błąd standardowy \\
\hline KOR & $-0,4740 \cdot 10^{-6}$ & $0,4130 \cdot 10^{-6}$ \\
NS $_{i, t}$ & $0,5650 \cdot 10^{-6}$ & $0,0497 \cdot 10^{-6}$ \\
$R P E_{i, t}$ & $-0,1360 \cdot 10^{-6 *}$ & $0,0497 \cdot 10^{-6}$ \\
$O P W_{i, t}$ & $-0,2530 \cdot 10^{-6}$ & $0,0706 \cdot 10^{-6}$ \\
$I N W_{i, t}$ & $4,9200 \cdot 10^{-6 * * *}$ & $1,2000 \cdot 10^{-6}$ \\
LL $_{i, t}$ & $0,3640 \cdot 10^{-6 * * *}$ & $0,1300 \cdot 10^{-6}$ \\
PPKB $_{i, t}$ & $-0,7680 \cdot 10^{-6 * *}$ & $0,0000 \cdot 10^{-6}$ \\
InWSR & $1,3500 \cdot 10^{-6 * * * *}$ & $4,2900 \cdot 10^{-6}$ \\
stała & $-1,5700 \cdot 10^{-6 * * *}$ & $0,5830 \cdot 10^{-6}$ \\
\hline
\end{tabular}

Uwagi:

*, **, *** oznaczają istotność statystyczną na poziomie odpowiednio: $10 \%, 5 \%$ i $1 \%$.

Źródło: Opracowanie własne.

Tabela 2.

Wyniki estymacji modelu objaśniającego indeks Giniego (model (2))

\begin{tabular}{lcc}
\hline & Zmienna objaśniająca & Błąd standardown \\
\hline $\ln K L_{i, t}$ & $-1,2240$ & 1,2209 \\
$\ln T F P_{i, t}$ & $0,5284^{* * *}$ & 0,1916 \\
$\ln O H_{i, t}$ & $-0,0201^{* *}$ & 0,0090 \\
$\ln K O R_{i, t}$ & $-0,2079$ & 0,2400 \\
$\ln O P W_{i, t}$ & $-0,5613^{* * *}$ & 0,1501 \\
stała & 1,2958 & 1,6621 \\
\hline
\end{tabular}

*, **, ${ }^{* * *}$ oznaczają istotność statystyczną na poziomie odpowiednio: $10 \%, 5 \%$ i $1 \%$.

Źródło: Opracowanie własne. 
Institutional competitiveness of the OECD countries

\begin{abstract}
Motivation: The paper attempts to investigate, whether or not institutional factors beyond those of solely economic nature can influence economic growth and income inequality in the OECD countries.

Aim: The purpose of this study is to examine the impact of institutional infrastructure connected with the public sector, proxied for by a set of institutional variables: corruption, protection of property rights, environmental policy stringency and judicial independence, on socioeconomic success of the OECD countrieśs societies.

Materials and methods: The paper introduces two econometric models estimated on annual panel data from 2005 to 2012 for a homogenous group of nineteen high income OECD countries. Two variables - economic growth and income inequality - were used in order to operationalise the socioeconomic success. The econometric model of economic growth, based on an institutions-augmented Solow model with human capital, was estimated by OLS mtehod. As for the problem of income inequalities, a fixed-effects model has been employed, which, like the growth model, takes both institutional and control variables into account.

Results: Results from the empirical analysis suggest that environmental policy stringency explains to a significant extent the variation in growth rates across nations. The only institutional variable being a significant source of differences in income inequality is protection of property rights. No significant effect of corruption on any of the explained variables was find, as well as judicial independence and protection of property rights on economic growth.
\end{abstract}

Keywords: institutional competitiveness; new institutional economics; public sector; economic growth; Gini coefficient JEL: B52; E02; O17; 043 
